\title{
Effects of vitamin D3 on the level of heat shock protein 70 and oxidative stress in human sperm: a pilot study
}

\author{
Mahin Taheri Moghadam ${ }^{1,2,3}$, Omid Hamidian ${ }^{2,4,5^{*}}$, Esrafil Mansouri ${ }^{1,2}$ and Roshan Nikbakht ${ }^{3}$
}

\begin{abstract}
Background: Vitamin D3 (Vit.D3) is an antioxidant that can improve sperm motility. However, the specific mechanisms of Vit.D3's effect on sperm are not yet elucidated. Since heat shock protein 70 (HSP70) and oxidative stress (OS) are effective in sperm motility and it has been shown that vitamin D3 is associated with these factors, thus this pilot study evaluated the effects of Vit.D3 on HSP70 and OS levels in normal and asthenozoospermic semen samples.
\end{abstract}

Results: In this study, the level of HSP70 proteins was evaluated by western blotting and immunocytochemistry in eight normal and nine asthenozoospermic samples. Additionally, malondialdehyde (MDA) assay and nitroblue tetrazolium (NBT) test were used for measuring OS. The results showed that the amount of HSP70 protein was higher in the groups treated with Vit.D3 compared to the control groups. Likewise, in normal and asthenozoospermic samples, OS was increased in treatment groups, but the increase was insignificant in asthenozoospermic samples.

Conclusion: According to the data, HSP70 and OS levels were increased in the sperm cells after incubation with Vit.D3; thus, vitamin D3 might improve sperm motility via these factors in vitro.

Keywords: Vitamin D3, HSP70, Oxidative stress, Sperm motility

\section{Background}

Infertility is one of the main worldwide concerns in the reproductive health field and it is estimated that $15 \%$ of all couples refer to infertility centers annually [1]. Sperm motility disorder is one of the main causes of male infertility [2].

It has been demonstrated that vitamin D3 can enhance sperm motility by regulating intracellular $\mathrm{Ca}^{2+}$ content [3]. However, the influence of vitamin D3 (Vit.D3) on the other mechanisms that contribute to sperm motility has not been yet fully clarified.

Heat shock protein 70 (HSP70) is a protein that can affect semen quality. This protein can increase cell

\footnotetext{
* Correspondence: hamidian.o@ajums.ac.ir

${ }^{2}$ Department of Anatomical Sciences, Faculty of Medicine, Ahvaz Jundishapur University of Medical Sciences, Ahvaz, Iran

${ }^{4}$ Ahvaz Jundishapur University of Medical Sciences, Ahvaz, Iran

Full list of author information is available at the end of the article
}

resistance and preserve cells from harmful effects of stress [4], which by itself can impair sperm motility [5]. Another study showed that a low level of HSP70 expression in sperm led to the decline of antioxidant enzymes' activities and sperm motility. Therefore, HSP70 protein is effective in controlling sperm movements [6].

Another important agent for sperm motility is oxidative stress (OS) [7]. OS is defined as a condition in which oxygen and oxygen-derived free radicals, known as reactive oxygen species (ROS), exceed the physiological level [8]. Controlled concentrations of ROS are required for normal sperm function, but in excessive levels, they overwhelm the body's antioxidant defenses, which could damage DNA, lipids, and proteins and result in impaired motility, concentration, and morphology of sperm. However, antioxidants such as Vit.D3 can

\section{Springer Open}

(c) The Author(s). 2020 Open Access This article is licensed under a Creative Commons Attribution 4.0 International License, which permits use, sharing, adaptation, distribution and reproduction in any medium or format, as long as you give appropriate credit to the original author(s) and the source, provide a link to the Creative Commons licence, and indicate if changes were made. The images or other third party material in this article are included in the article's Creative Commons licence, unless indicated otherwise in a credit line to the material. If material is not included in the article's Creative Commons licence and your intended use is not permitted by statutory regulation or exceeds the permitted use, you will need to obtain permission directly from the copyright holder. To view a copy of this licence, visit http://creativecommons.org/licenses/by/4.0/. 
react with ROS, assist in preventing OS onset, and preserve the spermatozoa's function [9].

Finally, since HSP70 and OS are effective in sperm motility, this study was conducted to evaluate the effects of Vit.D3 on the levels of these factors in sperm cells of normal and asthenozoospermic men. This was performed in order to characterize some possible mechanisms of Vit.D3 in improving sperm motility, and the results can be used to improve the quality of the reproductive process.

\section{Methods}

\section{Semen collection and processing}

This experimental study was carried out on discharged semen samples of IVF (in vitro fertilization) clinic of Imam Khomeini Hospital of Ahvaz Jundishapur University of Medical Sciences, Ahvaz, Iran, during a period from August 2016 to March 2017. This research was approved by the Ethics Committee of the Research Deputy of Ahvaz University of Medical Sciences (IR.AJUMS.REC.1395.235). Seventeen human semen samples were randomly collected and transferred to the Cellular and Molecular Research Center. After liquidation, samples were loaded on slides for analyzing sperm parameters (count, motility, morphology, and leukocytes percentage) and selecting normal and asthenozoospermic samples according to WHO's 2010 guidelines [10]. It should be noted that samples of men who had underlying disorders such as varicocele and infection, as well as cigarette smokers and those who were taking medications were excluded from this study. Each sample was washed twice with $1 \mathrm{ml}$ fresh sperm wash solution and centrifuged at $300 \times g$ for $5 \mathrm{~min}$. Then, $2 \mathrm{ml}$ fresh sperm wash was added to the cell plate which was then kept at a $45^{\circ}$ angle in an incubator at $37^{\circ} \mathrm{C}$ for $45 \mathrm{~min}$ in order to have the motile sperms swim up [11].

\section{Vitamin D3 treatment}

The supernatant of each sample was divided into two groups: One was considered the control group and the other received $20 \mu \mathrm{mol}$ of Vit.D3 (vitamin D3 (cholecalciferol) 300,000 IU/ml-Caspian company) as experimental group, and they were incubated for $1 \mathrm{~h}$ [11]. After incubation, $5 \mu \mathrm{l}$ of a well-mixed sample was placed on a glass slide and checked under a microscope at $x$ 400 magnification for sperm motility assessment. According to the WHO's definition [10], motility of spermatozoa is classified into the following groups: progressive motility (PR), spermatozoa moving actively, either linearly or in a large circle, regardless of speed; nonprogressive motility (NP), all other patterns of motility with the absence of progression, e.g. swimming in small circles, the flagellar force hardly displacing the head, or when only a flagellar beat can be observed; and immotility (IM), no movement of spermatozoa whatsoever.

\section{Western blotting}

Approximately $1.0 \times 10^{7}$ spermatozoa were mixed with lysis buffer (170 mg urea, $56 \mathrm{mg}$ thiourea, $14 \mathrm{mg}$ CHAPS, and $76 \mathrm{mg}$ Tris in $18 \mathrm{ml}$ PBS final volume) and $1 \mathrm{X}$ protease inhibitor solution on ice for $1 \mathrm{~h}$ and then centrifuged at $16000 \times g$ for $20 \mathrm{~min}$. The supernatant was frozen at $80^{\circ} \mathrm{C}$.

SDS-PAGE was performed on a $12 \%$ Bis-Tris gel [12]. Electrophoresis and electrotransfer to PVDF membrane were done for each step at $100 \mathrm{~V}$ for $70-100 \mathrm{~min}$. After transfer of proteins, PVDF membranes were blocked with $5 \%$ milk powder for $1 \mathrm{~h}$ at room temperature while being shaken. In the next step, the membranes were incubated with primary monoclonal anti-HSP70 (sc-373867) $(1 / 500)$ at $4{ }^{\circ} \mathrm{C}$ overnight and then with goat anti-mouse IgG-HRP secondary antibody (sc-2005) (1/5000) for $1 \mathrm{~h}$ at room temperature with shaking. Finally, the bands were detected by a molecular imaging apparatus. Anti- $\beta$ actin (sc-47778) was used as internal control [13].

\section{Immunocytochemistry}

For detection of HSP70 by immunocytochemistry, several smears were created from the samples and fixed with $4 \%$ paraformaldehyde for $10 \mathrm{~min}$. All the steps were carried out at room temperature in a humidified chamber. The slides were incubated for $5-10 \mathrm{~min}$ in $0.1-1 \%$ hydrogen peroxide and were blocked with $1.5 \%$ blocking serum. Then, primary and secondary antibodies (1:200) were applied to each slide for $1 \mathrm{~h}$, respectively. Negative control slides were treated with PBS alone during the primary antibody step; after that, slides were incubated in 1-3 drops of peroxidase substrate. Finally, the slides were checked under a microscope at $\times 400$ magnifications. Then, 100 cells were counted according to the staining intensity measurement method in three classes, including high staining, low staining, and colorless.

\section{Measurement of lipid peroxidation}

Lipid peroxidation in sperm cells was evaluated by thiobarbituric acid reactive substances (TBARS) method, which was used to measure malondialdehyde (MDA) level. Initially, sperm samples were lysed by the method of doing rapid freeze to $-80^{\circ} \mathrm{C}$ and thawing to $35^{\circ} \mathrm{C}$ for at least three times. Then, the samples were centrifuged at $4000 \times g$ for $10 \mathrm{~min}$ and the supernatant was used for the MDA assays [14].

Two hundred and fifty microliters of supernatant were added to a solution made from $1 \mathrm{ml}$ of $20 \%$ trichloroacetic acid and $1 \mathrm{ml}$ of $0.5 \%$ thiobarbituric acid. The mixture was then incubated in a boiling water bath at $95^{\circ} \mathrm{C}$ for $1 \mathrm{~h}$. After cooling, the samples were centrifuged at $4000 \times g$ for $15 \mathrm{~min}$ and the MDA content was measured by a spectrophotometer at $532 \mathrm{~nm}$. The MDA intensity of spermatozoa was determined by using various concentrations $(5-100 \mu \mathrm{mol} / \mathrm{dl})$ 
Table 1 Basic data of normal samples $(n=8)$ and asthenozoospermic samples $(n=9)$

\begin{tabular}{lll}
\hline Subject parameters & Normal sample $($ mean $\pm \mathrm{SE})$ & Asthenozoospermic sample $(\mathrm{mean} \pm \mathrm{SE})$ \\
\hline Sperm concentration $\left(\times 10^{6} / \mathrm{ml}\right)$ & $57.89 \pm 22.94$ & $67.74 \pm 26.22$ \\
Total motility (\%) & $62.22 \pm 9.70$ & $31.7 \pm 5.81$ \\
Progressive motility (\%) & $44.56 \pm 12.84$ & $17 \pm 7.86$ \\
Normal morphology (\%) & $42.33 \pm 5.52$ & $33 \pm 16.62$ \\
\hline
\end{tabular}

of tetraethoxypropane as standards and the results were expressed as $\mu \mathrm{mol} / \mathrm{dl}[15]$.

\section{NBT test}

Nitroblue tetrazolium (NBT) test was employed for assessing the level of intracellular ROS. Briefly, $200 \mu \mathrm{l}$ of a sperm sample was washed twice with $1 \mathrm{ml}$ PBS at $300 \times g$ for $10 \mathrm{~min}$. The washed spermatozoa was resuspended in $100 \mu \mathrm{L}$ PBS and mixed with an equal volume of $0.1 \%$ NBT, and the mixture was shaken $(10 \mathrm{mg}$ of nitroblue tetrazolium chloride powder in $10 \mathrm{ml} \mathrm{PBS}$ ) at $37^{\circ} \mathrm{C}$ for 45 min. After washing, the intracellular formazan crystals were solubilized in $60 \mu \mathrm{l}$ of $2 \mathrm{~mol} / \mathrm{l}$ of $\mathrm{KOH}$ and $2 \mathrm{~mol} / \mathrm{l}$ of DMSO. After $5 \mathrm{~min}$, the resulting color of the supernatant was measured by an ELISA reader at $655 \mathrm{~nm}$ [16].

\section{Statistical analysis}

Data analysis was performed using SPSS 23.0. All the values were expressed as mean \pm standard error. Due to the fact that data distribution was not normal, bootstrap test was used for comparison of mean values according to 95\% confidence interval (CI) in 95\% level. In order to analyze the results of all the western blot experiments, the protein bands' density was quantified by Image J software.

\section{Result}

\section{Semen analysis}

For determining normozoospermic and asthenozoospermic semen samples, concentration, morphology, total motility, and progressive motility of the sperms were assessed and the results are listed in Table 1. After incubating the samples with vitamin D3, their progressive motility was checked and the best samples were selected. These results are given in Table 2 .

\section{Western blotting analysis of HSP70 protein}

Western blotting analysis was performed to evaluate the amount of HSP70 protein in human sperm cells. HSP70 bands were detected in $70 \mathrm{kDa}$ line (Fig. 1). The density of bands was analyzed with image J software program and the results demonstrated that the amount of HSP70 protein in normal and asthenozoospermic samples was higher in the groups treated with Vit.D3 compared to the control groups $(\mathrm{CI}=0.0598-1.2735$ and $\mathrm{CI}=0.01-$ 0.48 for normal and asthenozoospermic samples, respectively) (Fig. 1) (Table 3).

\section{Immunocytochemistry analysis of HSP70 protein}

Immunocytochemistry study was carried out to further support the western blotting results. In this method, the sperms of the studied groups were counted in three categories of colored, light, and colorless, based on their color intensity. The results showed that high-staining cells were increased in the group treated with Vit.D3 (CI $=7.596-$ 27.375 in normal samples (Fig. 2) and CI = 10.934-22.141 in asthenozoospermic samples (Fig. 3)). The number of low-staining cells was decreased in these groups $(\mathrm{CI}=$ -19.63 to -5.75 in the normal group (Fig. 2) and $\mathrm{CI}=$ 18.95 to -6.873 in the asthenozoospermic samples (Fig. 3)). In addition, a statistically insignificant decrease was observed in a number of colorless cells in the treatment group compared to the control group in normal samples $(\mathrm{CI}=-8.412$ to 0.597$)$ (Fig. 2). Conversely, the decrease was significant in the asthenozoospermic samples in the treated group $(\mathrm{CI}=-7.0$ to -0.634 ) (Fig. 3).

The results indicated that Vit.D3 could increase the level of HSP70 protein in sperms of normal and asthenozoospermic samples.

\section{Effect of vitamin D3 on MDA level}

The MDA levels of normal and asthenozoospermic samples in the group receiving Vit.D3 as well as the untreated

Table 2 Mean of sperm motility from the samples after incubation with vitamin D3

\begin{tabular}{llll}
\hline Sample & Movement type & Treatment group (Vit.D3) & Control group \\
\hline Normal & PR (\%) & $79.71 \pm 10.54$ & $53.16 \pm 13.24$ \\
& NP (\%) & $20.29 \pm 11.41$ & $46.84 \pm 21.72$ \\
Asthenozoospermic & PR (\%) & $71.80 \pm 15.38$ & $3.83 \pm 12.29$ \\
& NP (\%) & $28.20 \pm 10.16$ & $56.17 \pm 2.77$ \\
\hline
\end{tabular}

$P R$ progressive motility, NP non-progressive motility; normal $(n=8)$; asthenozoospermic $(n=9)$ 


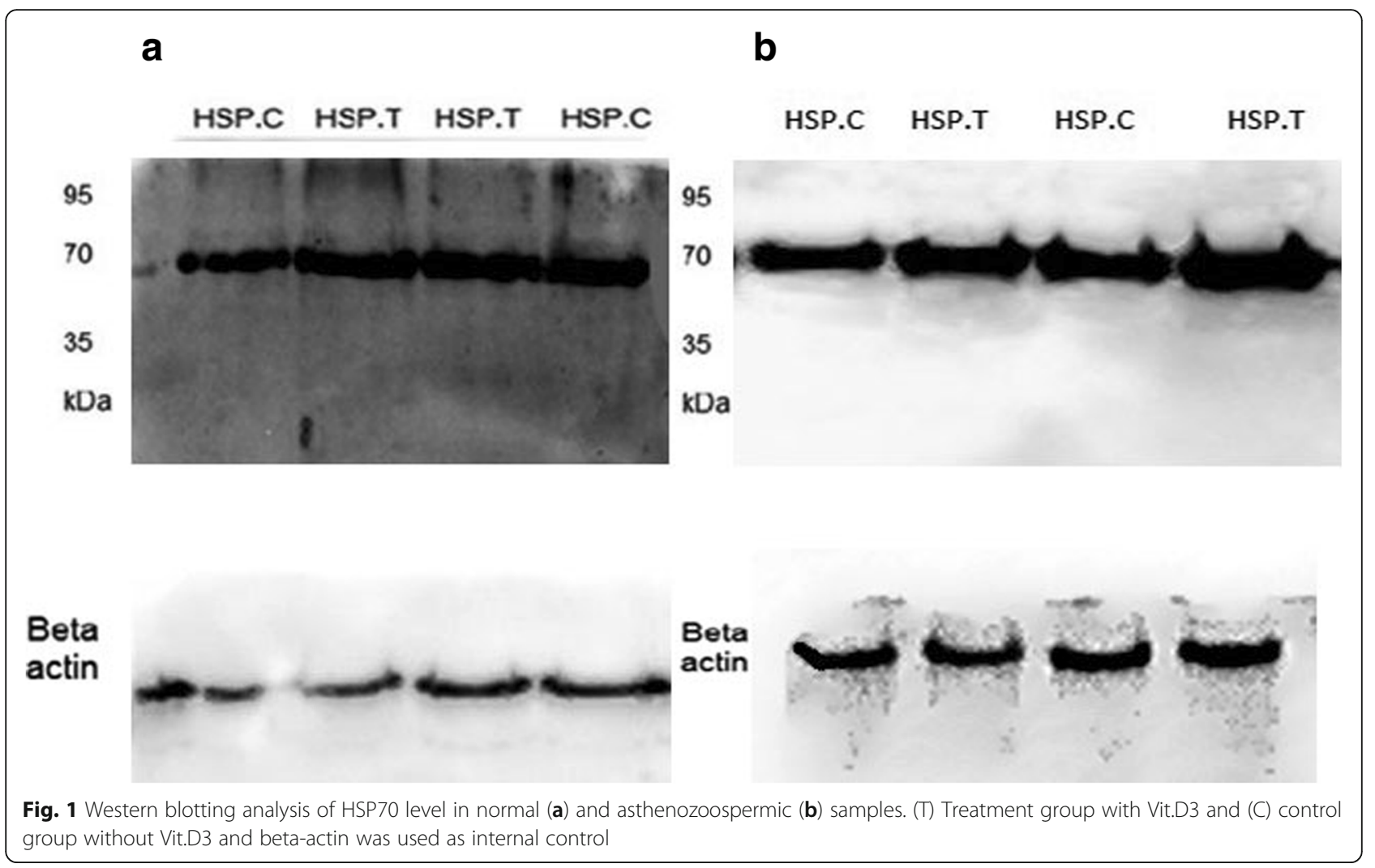

group are shown in Fig. 4. According to the data, the MDA level of the normal samples was significantly higher in the treatment group compared to the control group (CI $=0.00240-0.0336$ ) (Fig. 4). In the asthenozoospermic samples, an insignificant increase was observed in the treated group ( $\mathrm{CI}=-3.818$ to 5.446$)$ (Fig. 4).

\section{Effects of Vitamin D3 on intracellular ROS}

ROS generation in normal and asthenozoospermic semen samples was evaluated by the NBT test. Results showed that ROS generation in Vit.D3-treated group was significantly higher in the normal samples $(\mathrm{CI}=0.0025-0.048)$ (Fig. 5); moreover, ROS generation was increased in the treated group in the asthenozoospermic samples, but it was insignificant ( $\mathrm{CI}=-0.408$ to 0.048$)$ (Fig. 5).

\section{Discussion}

This is the first study that demonstrates the effects of Vit.D3 on HSP70 protein and OS in human sperm function. Motility is the main parameter of sperm and plays an important role in fertility [1]. It has been shown that
Vit.D3 can increase sperm motility by unknown mechanisms [17].

HSP70 is a protein that has been recognized to be effective in sperm motility [18]. In the current study, the results of western blotting and immunocytochemistry analysis showed that Vit.D3 significantly increased the level of HSP70 in normal and asthenozoospermic human sperm samples. Many other studies have been performed in order to understand the relationship between Vit.D3 and HSP70. A number of previous studies have shown that members of the HSP70 family of molecular chaperones are also known to interact with non-proteins, including metabolites of Vit.D3 [19].

Moreover, it has been revealed that Vit.D3 is a nontoxic inducer of HSP70 in the rat kidney. It has been reported that HSP70 expression is affected by Vit.D3 synthesis and VDR concentration [20]. In another study, $\mathrm{Wu}$ and colleagues suggested that overexpression of HSP70 enhanced mitochondrial metabolism of 25OHD3 (Vit.D3) in human kidney cells by enzymes that catalyze the synthesis of 1,25OH2D3 (Vit.D3) [21].

Table 3 Mean of optical density of HSP70 protein from samples after incubation with Vit.D3

\begin{tabular}{llll}
\hline Sample & Treatment group (Vit.D3) & Control group & Confidence interval \\
\hline Normal & $1.86 \pm 0.11$ & $1.20 \pm 0.36$ & $0.0598-1.2735$ \\
Asthenozoospermic & $0.90 \pm 0.21$ & $0.60 \pm 0.14$ & $0.01-0.48$ \\
\hline
\end{tabular}

The data shows the ratio of HSP70 protein optical density to beta-actin in the normal $(n=8)$ and asthenozoospermic $(n=9)$ samples 


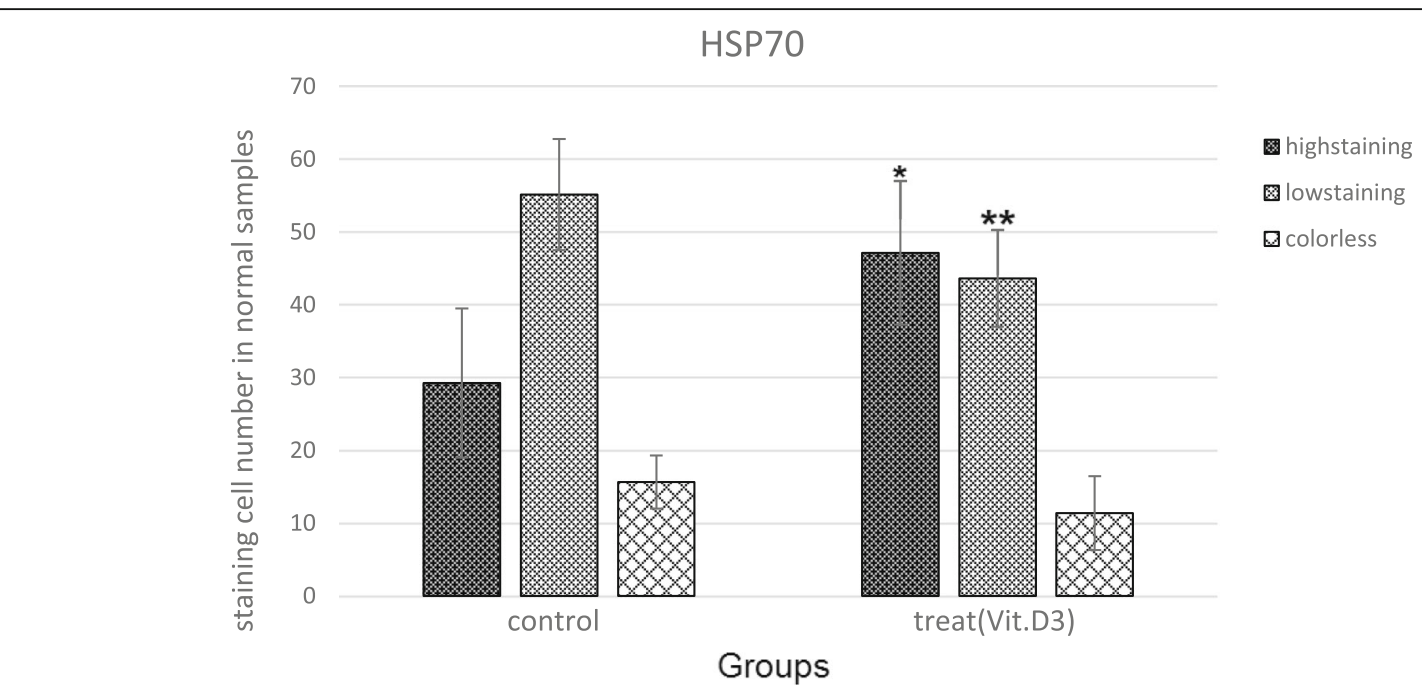

Fig. 2 Immunocytochemistry results for HSP70 protein in normal sample. Asterisk indicates a significant difference between the same type bars, ${ }^{*} \mathrm{Cl}=7.596-27.375$ and ${ }^{* *} \mathrm{Cl}=-19.63$ to -5.75

Therefore, according to these studies, the cause of increased HSP70 in the present study can be the presence of Vit.D3 in the surroundings of sperm cells. Moreover, HSP70 can have a determining role in the intracellular destination of vitamin D3 metabolites and promote Vit.D3 metabolite-directed signaling events in target cells. Therefore, this protein can mediate the metabolism and different actions of vitamin D3 [22]. On the other hand, some studies have demonstrated that there is a positive correlation between HSP70 level and sperm motility in bulls and boars. It has been explained that HSP70 proteins are examples of energy-supplying chaperone proteins and any increase in HSP70 level expression could limit ATP degradation in cells; as a result, sperms in this situation have sufficient energy to maintain and improve motility [18].

OS is another agent which could alter the quality of sperm motility [7]. In this study, the results of MDA and intracellular ROS measurements in normal samples showed that OS was significantly higher in Vit.D3treated groups in comparison with the untreated groups. In asthenozoospermic samples, the results showed an increase in the treated groups, albeit it was not significant.

Since this study was the first of its kind, its results were compared with other cells as well. Bhat and Ismail indicated that Vit.D3 ( $1 \mathrm{nmol}$ and $10 \mathrm{nmol}$ for 24 hours) can improve all the OS-related parameters in muscles by augmentation of superoxide dismutase activity.

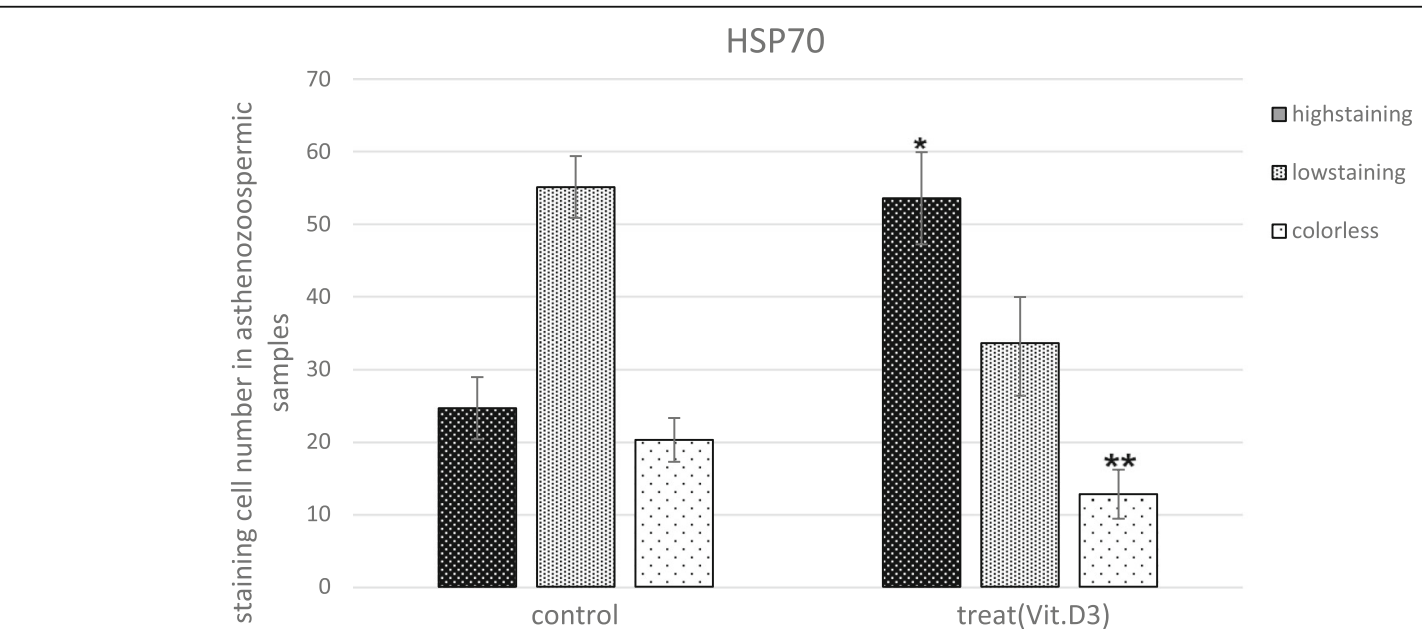

Fig. 3 Immunocytochemistry results for HSP70 protein in asthenozoospermic sample. Asterisk indicates a significant difference between the same type bars, ${ }^{*} \mathrm{Cl}=10.934-22.141$ and ${ }^{*} \mathrm{Cl}=-7.0$ to -0.634 


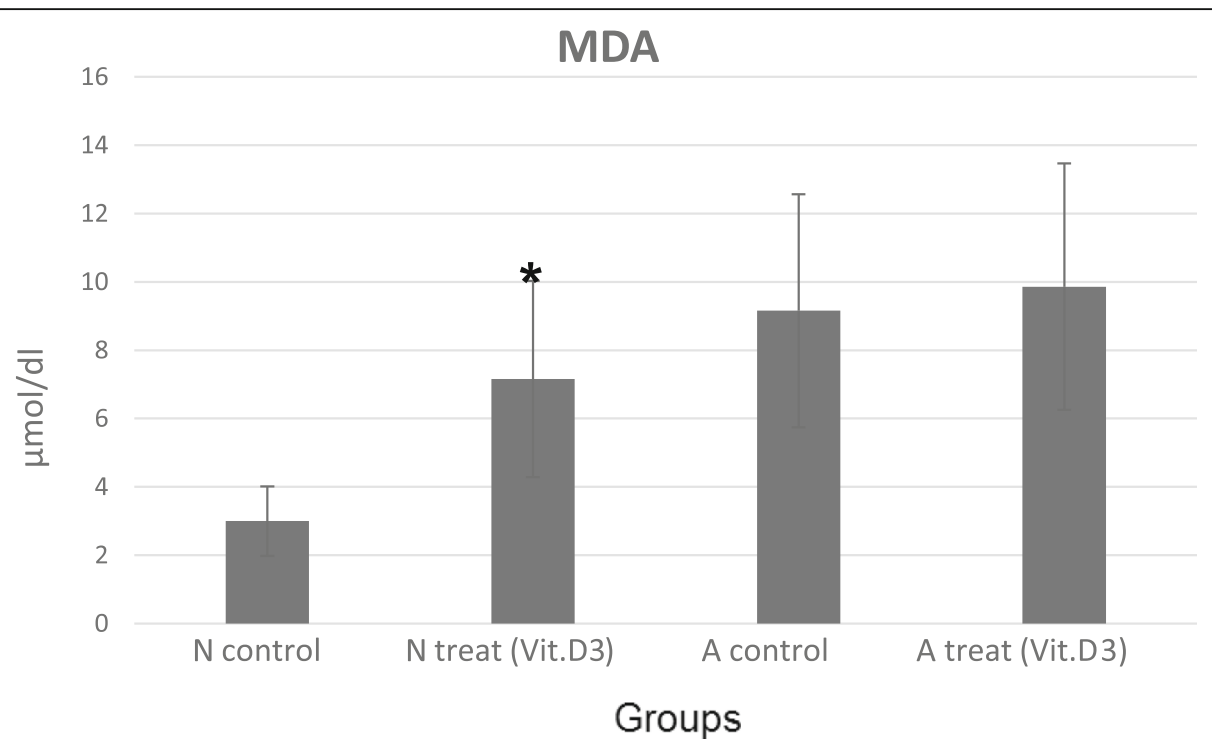

Fig. 4 Effects of Vit.D3 on MDA in normal (N) and asthenozoosperm (A) samples. The values are expressed as means of MDA concentration. *Significant difference as compared to the control group $[\mathrm{Cl}=0.0024-0.0336]$

Therefore, they suggested that $O S$ is increased in humans with Vit.D3 deficiency [23].

Similarly, it has been reported that pretreatment of keratinocyte cells with calcitriol, the hormonal form of Vit.D3, could protect cells against oxidative and heat stresses. Furthermore, authors stated that the effect of calcitriol was dose-dependent and its physiological concentration was $0.1 \mathrm{nmol}$ [24]. Another study reported that incubation of sperms with low concentrations of
$\mathrm{H}_{2} \mathrm{O}_{2}$ increases the amount of glutathione (GSH) in the sperm cells. Finally, accumulation of GSH increases the GAPDS activity and consequently improves sperm motility [25].

As already mentioned, Vit.D3 increased OS in this study, which is contradictory to prior studies and there are two possible reasons for this phenomenon: One is that this dose of vitamin D3 does not have an antioxidant effect on sperm cells because its effect is dose

\section{ROS}

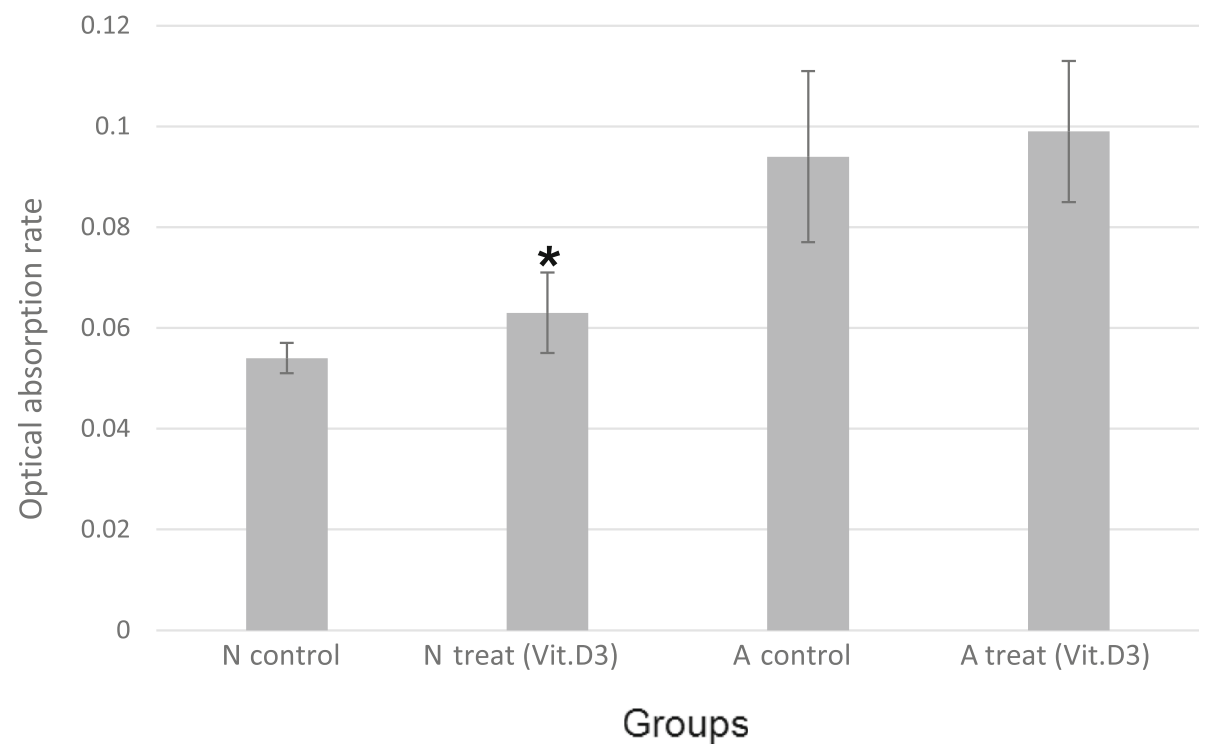

Fig. 5 Effects of Vit.D3 on intracellular ROS in normal (N) and asthenozoosperm (A) samples. The values are expressed as means of optical absorption rate. *Significant difference as compared to the control group $[\mathrm{Cl}=0.0025-0.048]$ 
dependent [24] and sperm is a sensitive cell with many polyunsaturated fatty acids in the plasma membrane and a small antioxidant mechanism in the cytoplasm [26]. The other possibility is that the increase in OS was small and had a positive effect on sperm cells, as one study has reported that low level of $\mathrm{H}_{2} \mathrm{O}_{2}$ can improve sperm motility by increasing GAPDS protein activity [25] and another study has shown that middle and high concentrations of $\mathrm{H}_{2} \mathrm{O}_{2}$ disrupt sperm motility due to a decrease in GAPDS activity [27]. Although GAPDS activity was not assessed in this study, the second possibility is more acceptable since sperm motility was in fact increased in the present study.

\section{Conclusion}

This study reveals that Vitamin D3 may improve sperm motility by increasing HSP70 protein. Furthermore, this vitamin can probably increase OS to a small degree in sperm cells and perhaps OS acts as a mediator in improving sperm cells motility.

\section{Abbreviations}

Vit.D3: Vitamin D3; HSP: Heat shock protein; OS: Oxidative stress; ROS: Reactive oxygen species; MDA: Malondialdehyde; NBT: Nitroblue tetrazolium

\section{Acknowledgements \\ This work has been extracted from the Master's degree thesis of Mr. Omid Hamidian. The authors hereby express their appreciation toward the laboratory technicians of IVF clinic of Imam Khomeini Hospital (Mrs. N. Pourshamsa, R. Arvaneh, and F. Lami) and the Cellular and Molecular Research Center of Ahvaz Jundishapur University of Medical Sciences for assisting them in collecting the samples. We would also like to thank Mr. Baback Dadizadeh for proofreading this article.}

\section{Authors' contributions}

MT contributed to the design of the study and also analyzed and interpreted the data and was a major contributor in writing the manuscript. $\mathrm{OH}$ contributed to all the experimental work and drafted the manuscript. EM was responsible for overall supervision. RN participated in sample collection. All the authors have read and approved the final manuscript.

\section{Funding}

This study was supported by Cellular and Molecular Research Center, Ahvaz Jundishapur University of Medical Sciences, Ahvaz, Iran (grant number IR.AJUMS.REC.1395.235).

\section{Availability of data and materials}

The datasets used and/or analyzed during the current study are available in case a reasonable request is made to the corresponding author.

\section{Ethics approval and consent to participate}

This research was approved by the Ethics Committee of the Research Deputy of Ahvaz University of Medical Sciences (IR.AJUMS.REC.1395.235) and no consent was obtained from patients in this study, because only their discarded semen fluid was used.

\section{Consent for publication}

Not applicable

\section{Competing interests}

The authors declare that they have no competing interests.

\section{Author details}

${ }^{1}$ Cellular and Molecular Research Center, Ahvaz Jundishapur University of Medical Sciences, Ahvaz, Iran. ${ }^{2}$ Department of Anatomical Sciences, Faculty of Medicine, Ahvaz Jundishapur University of Medical Sciences, Ahvaz, Iran. ${ }^{3}$ Fertility, Infertility and Perinatology Center, Imam Khomeini Hospital, Ahvaz Jundishapur University of Medical Sciences, Ahvaz, Iran. ${ }^{4}$ Ahvaz Jundishapur University of Medical Sciences, Ahvaz, Iran. ${ }^{5}$ Ghaletol, Iran.

Received: 29 February 2020 Accepted: 14 July 2020

Published online: 06 August 2020

\section{References}

1. Poongothai J, Gopenath T, Manonayaki S (2009) Genetics of human male infertility. Singapore Med J. 50(4):336-347

2. Agarwal A, Sekhon LH (2010) The role of antioxidant therapy in the treatment of male infertility. Human Fertility. 13(4):217-225

3. Yan W-J, Yu N, Yin T-L, Liu L, Yang J (2015) Can vitamin D supplementation be used as adjunctive treatment for oligozoospermia or asthenozoospermia accompanied with vitamin D deficiency? Asian J Androl 17(1):165

4. Huang S, Chen M, Lin E, Tsou H, Kuo Y, Ju C et al (2002) Effects of single nucleotide polymorphisms in the 5 '-flanking region of heat shock protein 70.2 gene on semen quality in boars. Anim Reprod Sci 70(1):99-109

5. Ren L, Li X, Weng Q, Trisomboon H, Yamamoto T, Pan L et al (2010) Effects of acute restraint stress on sperm motility and secretion of pituitary, adrenocortical and gonadal hormones in adult male rats. J Vet Med Sci 72(11):1501-1506

6. Hashemitabar M, Sabbagh S, Orazizadeh M, Ghadiri A, Bahmanzadeh M (2015) A proteomic analysis on human sperm tail: comparison between normozoospermia and asthenozoospermia. J Assist Reprod Genet 32(6):853

7. Bansal AK, Bilaspuri GS (2011) Impacts of oxidative stress and antioxidants on semen functions. Vet Med Int 2011:686137. https://doi.org/10.4061/2011/ 686137

8. Neuer A, Spandorfer S, Giraldo P, Dieterle S, Rosenwaks Z, Witkin S (2000) The role of heat shock proteins in reproduction. Hum Reprod Update 6(2): 149-159

9. Agarwal A, Virk G, Ong C, du Plessis SS (2014) Effect of oxidative stress on male reproduction. World J Mens Health 32(1):1-17

10. Organization WH (2010) WHO laboratory manual for the examination and processing of human semen. WHO press, Switzerland

11. Taheri Moghadam M, Hosseini G, Absalan F, Hashemi Tabar M, Nikbakht R. Effects of vitamin D on apoptosis and quality of sperm in asthenozoospermiai. JBRA Assisted Reproduction. 2020; DOI: https://doi.org/ 10.5935/1518-0557.20200009.

12. Margaryan H, Dorosh A, Capkova J, Manaskova-Postlerova P, Philimonenko A, Hozak P et al (2015) Characterization and possible function of glyceraldehyde-3-phosphate dehydrogenase-spermatogenic protein GAPD HS in mammalian sperm. Reprod Biol Endocrinol 13(1):15

13. Aquila S, Guido C, Middea E, Perrotta I, Bruno R, Pellegrino M et al (2009) Human male gamete endocrinology: 1alpha, 25-dihydroxyvitamin D3 (1, 25 $(\mathrm{OH}) 2 \mathrm{D3}$ ) regulates different aspects of human sperm biology and metabolism. Reprod Biol Endocrinol 7(1):140

14. Ghaffari MA, Rostami M (2012) Lipid peroxidation and nitric oxide levels in male Smokers' spermatozoa and their relation with sperm motility. J Reprod Infertil 13(2):81

15. Zribi N, Chakroun NF, Elleuch H, Abdallah FB, Hamida ASB, Gargouri J et al (2011) Sperm DNA fragmentation and oxidation are independent of malondialdheyde. Reprod Biol Endocrinol 9(1):47

16. Setyawan EMN, Kim MJ, Oh HJ, Kim GA, Jo YK, Lee SH et al (2016) Spermine reduces reactive oxygen species levels and decreases cryocapacitation in canine sperm cryopreservation. Biochem Biophys Res Commun 479(4):927-932

17. Anagnostis P, Karras S, Goulis DG (2013) Vitamin D in human reproduction: a narrative review. Int J Clin Pract 67(3):225-235

18. Zhang $X$, Hong J, Yan G, Wang Y, Li Q, Hu J. Association of heat shock protein 70 with motility of frozen-thawed sperm in bulls. Czech Journal of Animal Science. 2015;60(6):256-262.DOl: https://doi.org/10.17221/8239-CJAS

19. Gacad MA, Adams JS (1991) Endogenous blockade of 1, 25dihydroxyvitamin D-receptor binding in New World primate cells. J Clin Invest 87(3):996-1001

20. García IM, Altamirano L, Mazzei L, Fornés M, Cuello-Carrión FD, Ferder L et al (2014) Vitamin D receptor-modulated Hsp70/AT1 expression may 
protect the kidneys of SHRs at the structural and functional levels. Cell Stress Chaperones. 19(4):479-491

21. Wu S, Chun R, Gacad MA, Ren S, Chen H, Adams JS (2002) Regulation of 1 , 25-dihydroxyvitamin $\mathrm{D}$ synthesis by intracellular vitamin $\mathrm{D}$ binding protein1. Endocrinology. 143(10):4135-4138

22. Chun R, Gacad MA, Hewison M, Adams JS (2005) Adenosine 5'triphosphate-dependent vitamin $\mathrm{D}$ sterol binding to heat shock protein-70 chaperones. Endocrinology. 146(12):5540-5544

23. Bhat $M$, Ismail A (2015) Vitamin $D$ treatment protects against and reverses oxidative stress induced muscle proteolysis. J Steroid Biochem Mol Biol 152:171-179

24. DIKER-COHEN T, Koren R, Liberman UA, Ravid A (2003) Vitamin D protects keratinocytes from apoptosis induced by osmotic shock, oxidative stress, and tumor necrosis factor. Ann N Y Acad Sci 1010(1):350-353

25. Evdokimov V, Barinova K, Turovetskii V, Muronetz V, Schmalhausen E (2015) Low concentrations of hydrogen peroxide activate the antioxidant defense system in human sperm cells. Biochemistry (Moscow). 80(9):1178-1185

26. Trrdá E, Kováčik A, Tušimová E, Paál D, Mackovich A, Alimov J et al (2016) Antioxidant efficiency of lycopene on oxidative stress-induced damage in bovine spermatozoa. J Anim Sci Biotechnol 7(1):50

27. Elkina YL, Atroshchenko M, Bragina E, Muronetz V, Schmalhausen E (2011) Oxidation of glyceraldehyde-3-phosphate dehydrogenase decreases sperm motility. Biochemistry (Moscow). 76(2):268-272

\section{Publisher's Note}

Springer Nature remains neutral with regard to jurisdictional claims in published maps and institutional affiliations.

\section{Submit your manuscript to a SpringerOpen ${ }^{\circ}$ journal and benefit from:}

- Convenient online submission

- Rigorous peer review

- Open access: articles freely available online

- High visibility within the field

- Retaining the copyright to your article

Submit your next manuscript at $\boldsymbol{\nabla}$ springeropen.com 